\title{
DEVELOPMENT OF BIOREACTOR TO ENRICH THE PROTEIN OF AGRICULTURAL RESIDUES
}

\section{Khairy, M.F.A ${ }^{1}$,, A.A.I Mohamed ${ }^{2}$ and M. M. N. KHLIL ${ }^{3}$}

\section{ABSTRACT}

The present study aims to develop a simple bioreactor to enrich the protein of rice straw using solid-state fermentation. laboratory experiments were carried out at Testing and Research Station for Tractor and Farm Machinery, Alexandria governorate, Egypt to study the effect of three bioreactor temperature levels $T_{1}\left(25^{\circ} \mathrm{C}\right), T_{2}\left(35^{\circ} \mathrm{C}\right)$, and $T_{3}$ $\left(45^{\circ} \mathrm{C}\right)$ and three rice straw moisture levels $M_{1}(25 \%), M_{2}(50 \%)$ and $M_{3}(65 \%)$ on fungus growth activity on rice straw under solid state fermentation by Trichoderma harzinaum F-418 fungi (TH) and molasses, valvic solution additive with controlled temperature and moisture at fermentation time $(1,2,3,4$, and 5 days) to determine the optimum conditions of fungal treatment in terms of moisture and temperature. Parameters related to microbial growth crude protein content (CP\%), and crude fiber (CF\%) were measured every 24 hours and compared with crude protein content \% (CP\%), and crude fiber \% $(\mathrm{CF} \%)$ of rice straw before treatment (control treatment). The obtained results can be summarized as follows: The highest crude protein and the lowest crude fiber values were obtained at the temperature of $35^{\circ} \mathrm{C}$ and the moisture content of $65 \%$ after 4 and 5 days. The best value of crude protein was $5.88 \%$ which increased $103 \%$ of the control treatment and the best value of crude fiber content was $28.35 \%$ by decreasing $30 \%$ of the control treatment. It is evident that these values demonstrated good operation of fermentation in bioreactor.

1. Prof. of Ag. Power and farm machinery Dept., Faculty of Ag. Eng., Al-Azhar U., Cairo, Egypt.

2.Head Researcher, Agricultural Engineering Research Institute, Agricultural Research Centre, Egypt.

3.Associate researcher, Agricultural Engineering Research Institute, Agricultural Research Centre, Egypt. 


\section{INTRODUCTION}

7 here is a wide gap between animal feeds requirements and the available. The available local feeds are not sufficient completely 1 to cover the nutritional requirements of the Egyptian livestock. Crop residues from rice plantation such as rice straw, rice husks are abundant in Egypt. Rice straw is unique relative to other cereal straws being high in silica and lignin with low digestibility and protein content and contains considerable amounts of cellulose and hemicellulose about $65 \%$ of the total dry weight and $18 \%$ lignin. Rice straw in developing countries is used as a main feed for ruminants (Safa et al. 2011).

Hanafi et al. (2012) concluded that although several treatments have been used to improve the degradability and voluntary intake of rice straw, such as physical or chemical treatments, the practical use of these treatments is still restricted in terms of safety concerns, costs and potentially negative environmental consequences. Hathout and ElNouby (1977) pointed that the aim of mechanical treatments is to increase the digestibility of roughages and to increase the quantity which can be eaten by animals without any harmful effect on their weight gain or productive performance. Mechanical treatment like grinding can improve the digestion of roughages because this treatment increase the surface area of roughages for rumen microbes digestive enzymes and increase voluntary intake. Jonathan et al. (2012) investigated the bioconversion of sorghum and rice straw into value-added ruminant feed using Pleurotus pulmonarius in solid state fermentation over a period of forty days. The results obtained show a high positive correlation in the degradation of sorghum stalk and rice straw with an increase in the fermentation period. Sorghum stalk showed high digestibility compared to rice straw used for this study. The chemical composition results showed significant differences of $(\mathrm{P}<0.05)$, and high digestibility for the two substrates as the days of fermentation increases. Roussos et al. (1993) developed a pilot-scale packed-bed bioreactor with internal heat transfer plates, called the "Zymotis" bioreactor. The outer casing was acrylic, and it was $65 \mathrm{~cm}$ high, $50 \mathrm{~cm}$ wide, and $40 \mathrm{~cm}$ deep from front to back. This gave a total volume of $130 \mathrm{~L}$, with a working capacity of 100 L. The aeration rate was varied from 0.1 to $0.2 \mathrm{~L} \mathrm{~h}^{-1} / \mathrm{g}$-dry-substrate. 
Robinson and Nigam (2003) mentioned that there are three basic groups of reactor exist for solid state fermentation (SSF), these May be distinguished by type of mixing and aeration used. In laboratory scale, SSF occurs mainly in flasks and the following reactors used for larger scal product formation. They also added that Packed bed reactors, usually in the form of a column, have emerged over the past 20 years as a potential alternative to the previously mentioned reactors. Disadvantages associated with packed bed column bioreactors for SSF include difficulties in obtaining the product, non-uniform growth, poor heat removal and scale-up problems. pandey et al. (2001) mentioned that the use of tray fermenters in large scale production is limited as they require a large operational area and tend to be labor intensive with mechanical handling also being difficult. It can be seen that the lack of adaptability of this type of fermenter makes it an unattractive design for any largescale production. They added that growth of the inoculums in drum bioreactors is considered to be better and more uniform than that in tray fermenters. Fungal cultures are prone to damage in both rotating drum bioreactors and mixed reactors, as the increased sheer forces through mixing affecting the ultimate product yield being compromised. Although the mass heat transfer, aeration and mixing of the substrate is increased, in drum reactor, damage to inoculums and heat build-up through sheer forces may affect the final product yield. Application of drum reactor for large-scale fermentation also poses handling difficulties. Stuart et al. (1999) showed that drum bioreactors are designed to allow adequate aeration and mixing of the solid, whilst limiting the damage to the inoculums or product (sheer forces or heat build-up). Mixing and aeration of the medium has been explored in two ways by rotating the entire vessel or as showed by Negal et al. (2001) by various agitation devices such as paddles and paffles. Lonsane et al. (1992) concluded that rotating or the use of agitation can be carried out on a continuous or periodic basic, promoting surface mass heat transfer and a more uniform distribution of nutrients.

The objectives of the present study were:

1. To develop a new bioreactor for protein enrichment of agricultural residues. 
2. To determine the effect of biological treatments on the chemical composition of treated rice straw in terms of temperature, moisture content and fermentation time.

\section{MATERIALS AND METHODS}

\subsection{Model development}

The present study aims to develop a simple bioreactor to create optimal conditions which is necessary for accepted final fodder production. The suggested bioreactor model is a vertical cylinder with a paddle mixer mounted on a shaft running along the central axis of the bioreactor and rotate within the drum. The drum is surrounded by a water-jacket to control bioreactor bed temperature. This bioreactor was made from stainless steel to avoid rusting and to be good heat conduction. Its dimensions are $40 \mathrm{~cm}, 50 \mathrm{~cm}$ and $80 \mathrm{~cm}$ inner, outer diameter and length respectively. The total volume of the bioreactor is $100 \mathrm{~L}$. the geometric ratio (H/D) of bioreactor model was about 2 according to Sangsurasak et al. (1997). Stirred-drum of bioreactor is developed to allow adequate mixing of the rice straw and as a result medium aeration. Mixing and aeration of the medium have been furnitured by some devices such as paddles, air flowing in both side of bioreactor by two inlet vertical pipes with diameter of $1.27 \mathrm{~cm}$, and excess gas escaping through an outlet valve. Three analog temperature devices were installed through the bioreactor bed and arranged radically with equal distances to measure the bed temperature profile. Mechanical thermostat composed of heater, control lever and probe was used to adapt the bed temperature according to the optimum temperature $\left(35^{\circ} \mathrm{C}\right)$. The heater was merged with the water jacket which surrounds the reactor chamber to release heat to the bed chamber until reaching the suitable temperature, the probe was inserted in the space inside the reactor chamber to connect or disconnect the heater. The schematic diagram of stirred-drum bioreactor which manufactured and used in the experiments was illustrated in Figs. (1 and 2).

\subsection{Operational parameters:}

In this study two operational parameters were applied, three levels of Substrate temperatures, $\mathrm{T}_{1}, \mathrm{~T}_{2}$ and $\mathrm{T}_{3}\left(25,35\right.$ and $\left.45^{\circ} \mathrm{C}\right)$ and three levels of substrate moisture content, $\mathrm{M}_{1}, \mathrm{M}_{2}$ and $\mathrm{M}_{3}(25,50$ and $65 \%)$. 

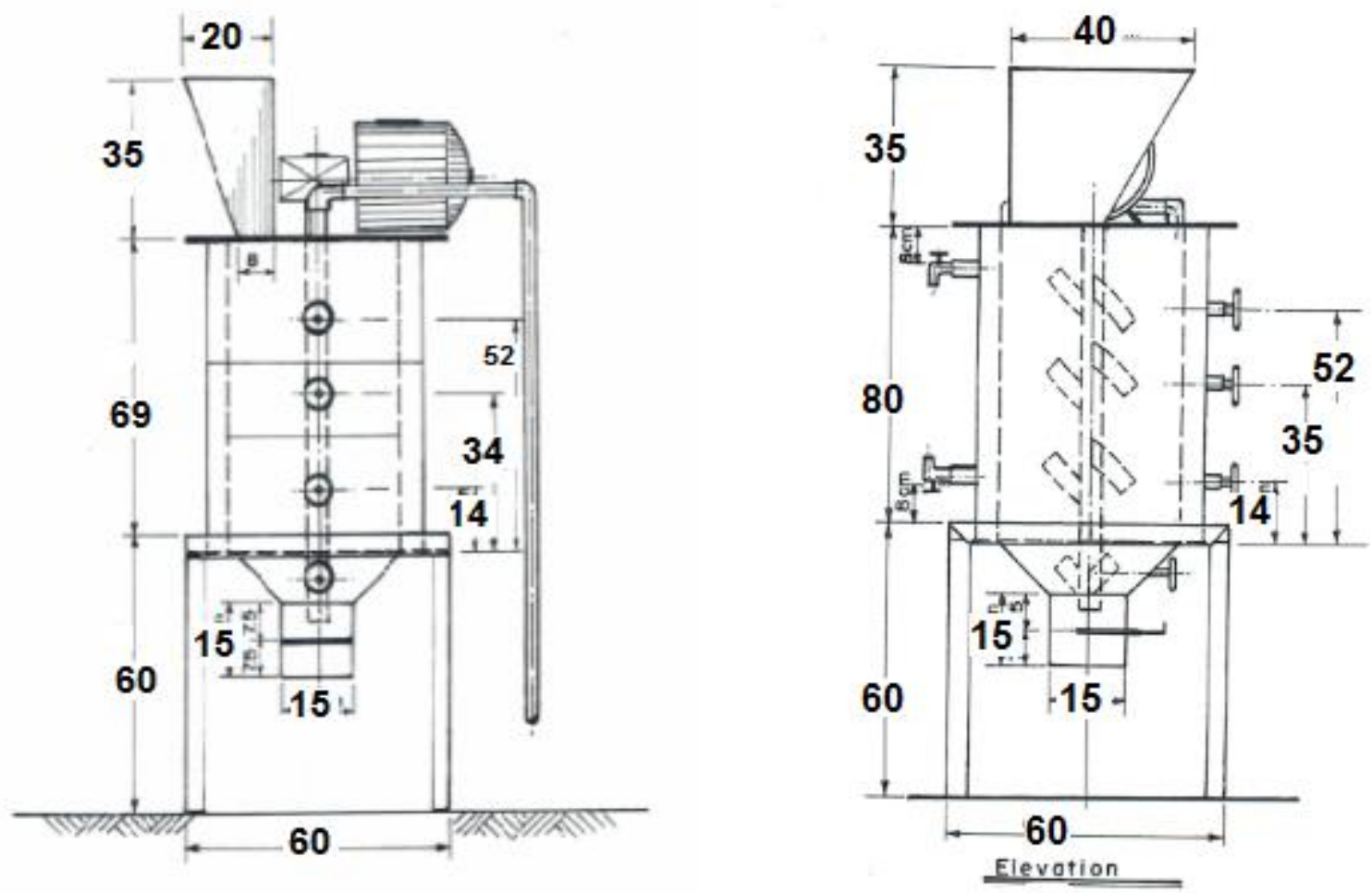

Sigevien

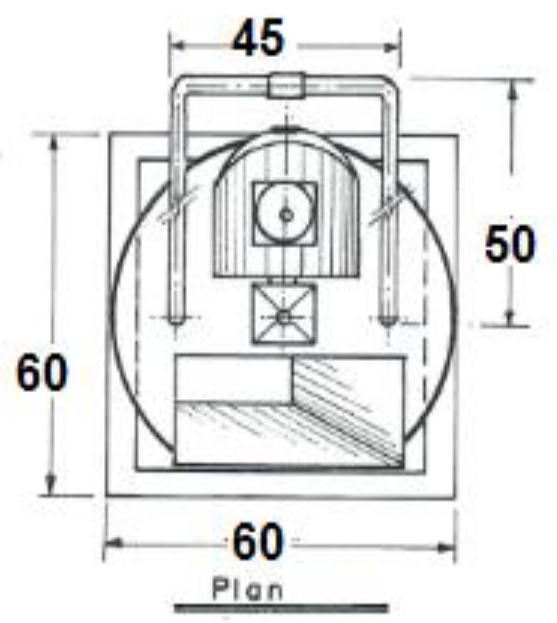

Scale 1: 100 Dimensions in $\mathrm{cm}$

Figure (1): Elevation, side view and plan of the developed bioreactor. 

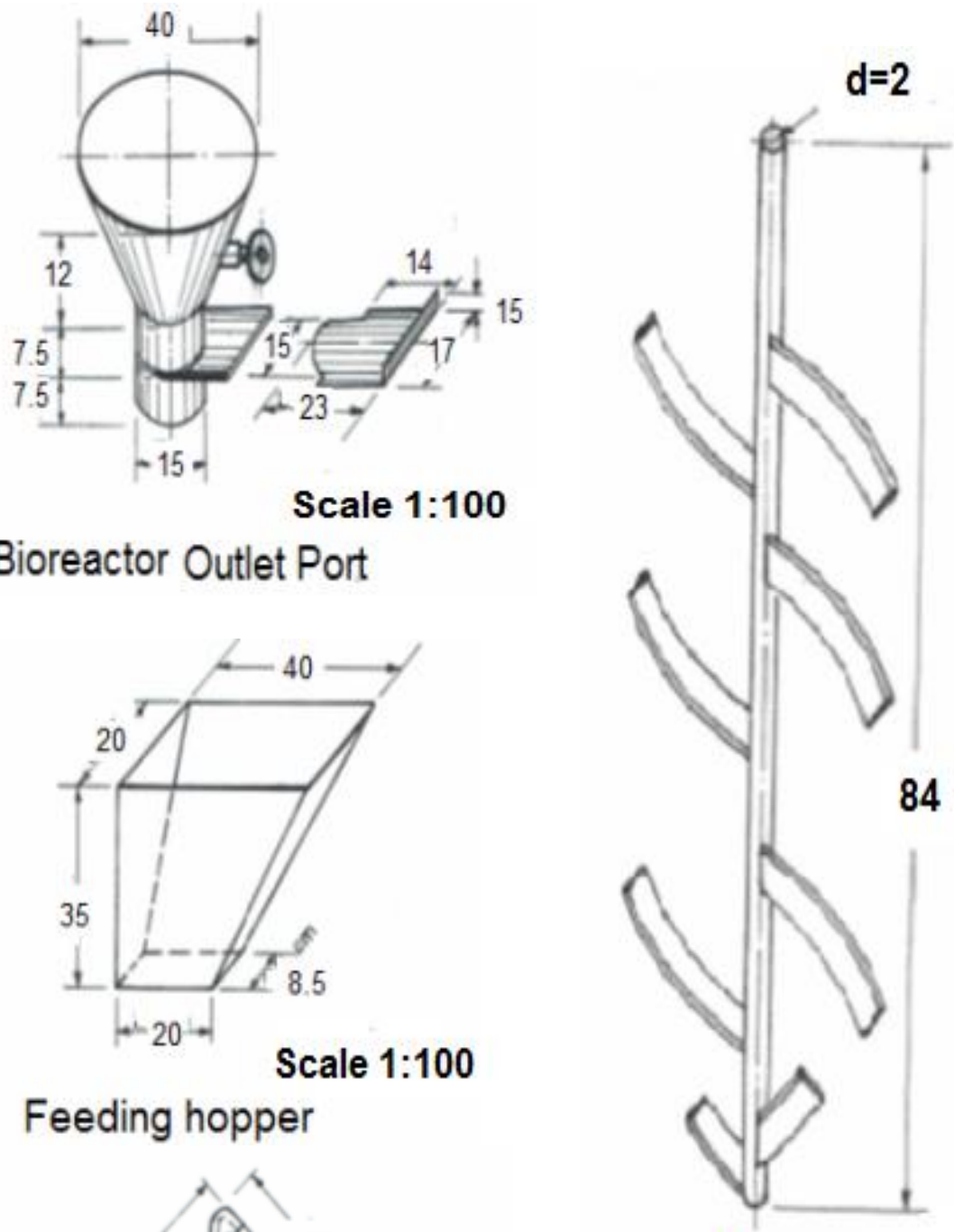

\section{Mixer}

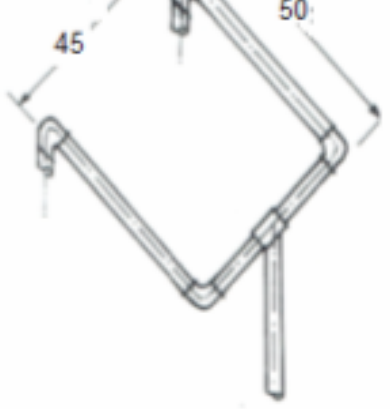

Scale 1:100

Aeration tube

Dimensions in $\mathbf{c m}$

Figure (2): The internal parts of the developed bioreactor. 
The course of fermentation time was 5 days and the measured parameters which related to microbial growth were Crude protein $(\mathrm{CP} \%)$ and Crude fiber (CF\%). The shaft was rotated 15 min every $24 \mathrm{~h}$ before taking samples to remove excess heat and prevent overheating of the system. The aeration rates were natural. Air was flowing in both side of bioreactor by two inlet vertical pipes. The laboratory experiments were carried out in the bioreactor at Testing and Research Station for Tractor and Farm Machinery, Alexandria governorate, Egypt to study the effect of three temperature levels $\mathrm{T}_{1}\left(25^{\circ} \mathrm{C}\right), \mathrm{T}_{2}\left(35^{\circ} \mathrm{C}\right)$, and $\mathrm{T}_{3}\left(45^{\circ} \mathrm{C}\right)$ and three moisture levels $\mathrm{M}_{1}(25 \%), \mathrm{M}_{2}(50 \%)$ and $\mathrm{M}_{3}(65 \%)$ in triplicates for each treatment on fungus growth activity on rice straw under solid state fermentation by Trichoderma harzinaum F-418 fungi and molasses, valvic solution additive with controlled temperature and moisture at different fermentation time $(1,2,3,4$, and 5 days) to determined the optimum conditions of fungal treatment in terms of moisture and temperature to compare the chemical analysis of rice straw after fungal treatment Crude protein $(\mathrm{CP} \%)$, Crude fiber $(\mathrm{CF} \%)$ with the chemical analysis of rice straw before fungal treatment (control treatment).

\subsection{Materials of study:}

Rice straw Sakha 101 were obtained from Agricultural management kafer El-dawar El-Beheira, governorate, was used as substrate for feeding production, while (Trichoderma harzinaum F-418 fungi), molasses, and valvic solution were obtained from the Biofertilizers Production Unit, Agric. Microbiology. Dept., Soils, Water and Environmental Research Institute. (SWERI) Agric. Res. Center (ARC), Giza, Egypt.

\subsection{Preparation of inocula:}

The microorganism was Trichoderma harzianum supported from the Biofertilizers Production Unit, Agric. Microbiology. Dept., Soils, Water and Environmental Research Institute. (SWERI) Agric. Res. Center (ARC), Giza, Egypt. Trichoderma was grown on a potato dextrose agar (PDA) according to ATCC (1992) and incubated at $28^{\circ} \mathrm{C}$ for $48 \mathrm{~h}$. on a rotary shaker. Trichoderma culture was injected into a sterilized carrier one day before sowing to guarantee the efficiency of rice straw inoculation with the fungi. 


\subsection{Preparation of rice straw:}

The rice straw was chopped handly by a small cutter to $2-3 \mathrm{~cm}$ of length according to recommendations of Smail et al., (1995) and treated with Trichoderma harzianum F-418 fungi. The moisture content of the rice straw was $14 \%$ then adjusted to three levels M1(25\%), M2(50\%) and M3(65\%) by spraying solution of water, $4 \%$ molasses, $2 \%$ valvic and Trichoderma harzianum $\mathbf{F - 4 1 8}$ fungi by handy machine gun according quantity of the solutions to be added according to the following equation of Bart-Plange et al. (2012) and mixed well and left For 24 hours then

$$
Q=\frac{W_{i}\left(M_{f}-M_{i}\right)}{100-M_{f}}
$$

\section{where:}

\section{$Q \quad$ Is the mass of solutions to be added in $\mathrm{kg}$ \\ $W_{i}$ is the initail mass of the sample in $\mathbf{~ g g}$ \\ $M_{i}$ is the initial moisture content of the sample in \% $\mathrm{db}$ and $M_{f}$ is the final moisture content in \% db}

the moisture content of the sample at intervals was measured by a hay moisture meter until proven moisture content of the sample by the ratio required adding. The treated chopped straw well mixed with specific fungal prepared culture at $20 \%$ by weight and left for 5 days into bioreactor $100 \mathrm{~L}$ capacity. The moisture was chosen according to the studies of Abdel-Azim et al. (2011) and El-Ashry et al. (2002) and each experiment was repeated three times, which leads to 135 experiments for measure the crude protein $\mathrm{CP} \%$ and crude fiber $\mathrm{CF} \%$ in this experiment to determined the optimum conditions of fungal treatment in terms of moisture and temperature.

\subsection{Chemical analysis:}

The Proximate chemical analysis supported from the Soil Salinity and Alkalinity Laboratory, Soils, Water and Environmental Research Institute (SWERI), The Proximate chemical analysis of raw material (rice straw 
before treatment) and rice straw after treatment and concentrate samples were carried out to determine Crude protein ( $\mathrm{CP} \%)$, Crude fiber $(\mathrm{CF} \%)$, according to the Association of Official Analytical Chemists AOAC (1995).

\section{1 - Crude protein (CP\%)}

Total nitrogen was determined by Kjeldahl method. To estimate the Crude protein $(\mathrm{CP} \%)$, the measured total nitrogen was multiplied by factor 6.25.

\section{2 - Crude fiber (CF\%)}

The sample, $2 \mathrm{~g}$, was boiled with $200 \mathrm{ml}$ of $1.25 \% \mathrm{H}_{2} \mathrm{SO}_{4}$ in $600 \mathrm{ml}$ beaker for $30 \mathrm{~min}$. The solution was filtered through Buchner and boiled in $200 \mathrm{ml} 1.25 \mathrm{NaOH}$ for $30 \mathrm{~min}$. The sample was filter again and washed with $75 \mathrm{ml}$ boiled $\mathrm{H} 2 \mathrm{O}$ and $25 \mathrm{ml} 95 \%$ alcohol. The residual was transferred to the crucible and dried at $130^{\circ} \mathrm{C}$ for $2 \mathrm{~h}$. Cooled in the desicator and weighted. Ignited $30 \mathrm{~min}$ at $600^{\circ} \mathrm{C}$ cooled again in the desicator and weighted. Percent of fiber is calculated by the difference of the sample residue weight before and after the ignition divided by the sample weight (AOAC, 1995).

\subsection{Statistical analysis:}

The studied experiments were carried out as factorial experiments in Randomized Complete Block Design (RCPD) in three replications. Least Significant Differences at 0.05 probability level (LSD 0.05) was calculated to compare the differences between treatment means according to Snedecor and Cochran (1971).

\section{RESULTS AND DISSCUSSION}

\section{1. Crude protein content" CP" (\%)}

The crude protein content $(\mathrm{CP} \%)$ of rice straw before fungal treatment (control treatment) was $2.90 \%$. The effect of fermentation time (days) on crude protein content $\mathrm{CP}(\%)$ at three temperature levels $\left(\mathrm{T}_{1}, \mathrm{~T}_{2}\right.$ and $\mathrm{T}_{3}$ $\left.{ }^{\circ} \mathrm{C}\right)$ and three moisture levels $\left(\mathrm{M}_{1}, \mathrm{M}_{2}, \mathrm{M}_{3} \%\right)$ for treated rice straw with Trichoderma harzinaum F-418 (TH) are shown in Fig. (3).The statistical analysis of crude protein content (CP \%) data showed that it was significant effect by temperature, moisture and fermentation time. Also, it can be noticed that, crude protein content $\mathrm{CP} \%$ increases with the 
increase of fermentation time until 4 and 5 days for all temperature and moisture levels under study. Crude protein values were 5.10, 5.45 and
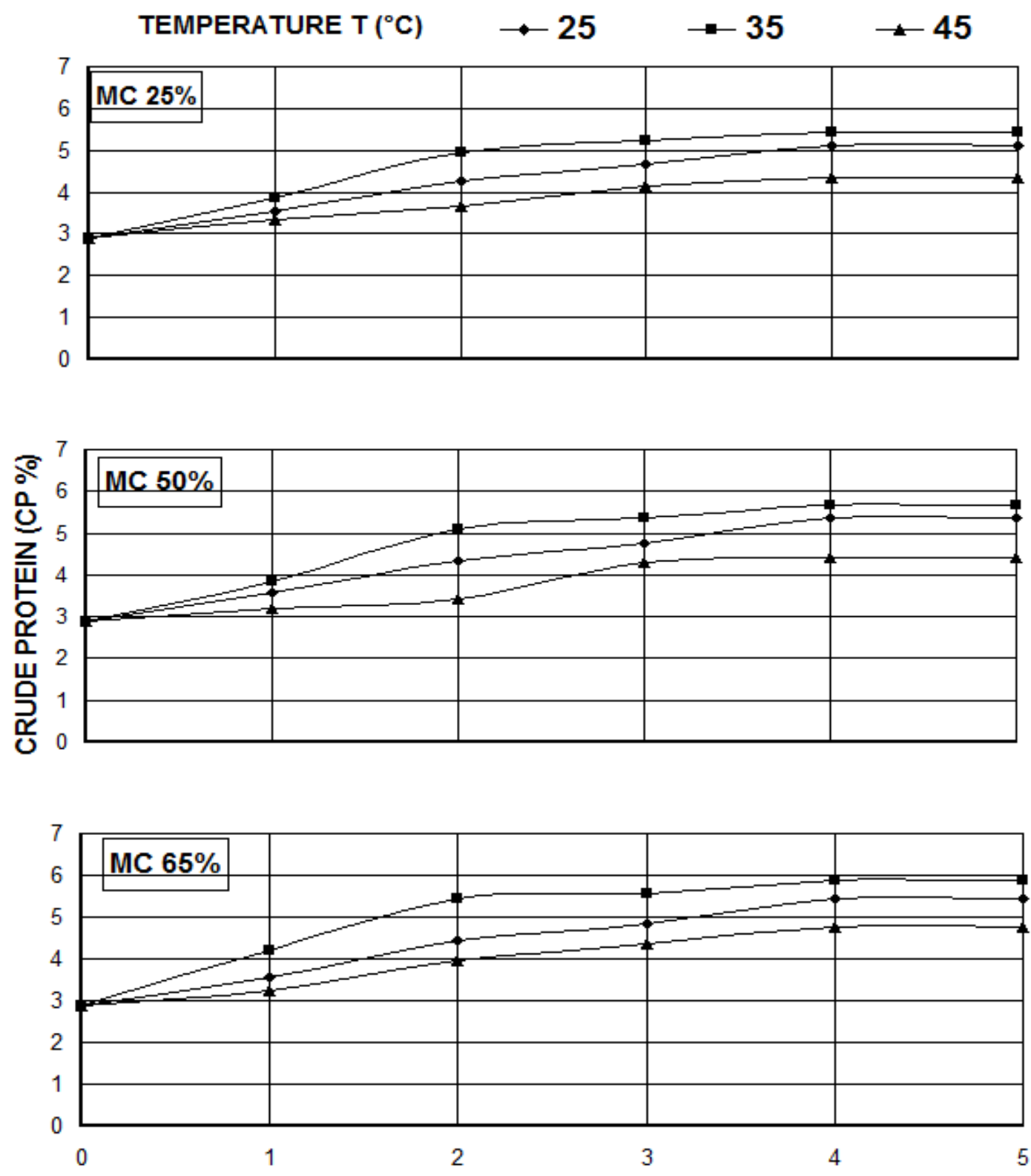

FERMENTATION TIME (DAYS)

Figure (3): The effect of fermentation time (days) on crude protein content $\mathrm{CP}(\%)$ at different temperature and moisture levels. 
4.33 for $\mathrm{T}_{1}, \mathrm{~T}_{2}$ and $\mathrm{T}_{3}$ respectively at moisture content $\mathrm{M}_{1}(25 \%)$ after 4 and 5 days. While these values were $5.35,5.65$ and 5.35 for $\mathrm{T}_{1}, \mathrm{~T}_{2}$ and $\mathrm{T}_{3}$ respectively at moisture content $\mathrm{M}_{2}(50 \%)$. At $\mathrm{M}_{3}(65 \%)$ the crude protein content values were 5.45, 5.88 and 4.78 after 4 and 5 days for $\mathrm{T}_{1}, \mathrm{~T}_{2}$ and $\mathrm{T}_{3}$ respectively. It is obvious that the best value of crude protein content was $5.88 \%$ obtained from the treatment $\mathrm{T}_{2} \mathrm{M}_{3}$ by increasing $103 \%$ of control treatment. While treatment $\mathrm{T}_{2} \mathrm{M}_{2}$ gave $5.65 \%$ of crude protein content by increasing $95 \%$. At treatment $\mathrm{T}_{2} \mathrm{M}_{1}$, it was $5.45 \%$ by increasing $88 \%$. This may be due to the capture of excess nitrogen by aerobic microbes and conversion of the same into microbial protein during solid-state fermentation. Generally, the biological treatment with Trichoderma harzinaum $\boldsymbol{F}-\mathbf{4 1 8}$ fungi (TH) was led to crude protein augmentation and reduces the crude fiber. Similar results were reported by Langer et al. (1980). This may be because the bioreactor was designed to allow adequate aeration and mixing of the substrate. Mixing and aeration have been explored by rotating paddles mounted on a shaft along the central axis. The growth of the inoculums in bioreactor is considered to be better and more uniform. Also water jacket around bioreactor removed the excess heat.

\subsubsection{Crude fiber content" CF" (\%)}

Fig. (4) shows the effect of fermentation time (days) on crude fiber content $\mathrm{CF} \%$ at three temperature levels $\left(\mathrm{T}_{1}, \mathrm{~T}_{2}\right.$ and $\left.\mathrm{T}_{3}{ }^{\circ} \mathrm{C}\right)$ a and three moisture levels $\left(\mathrm{M}_{1}, \mathrm{M}_{2}, \mathrm{M}_{3} \%\right)$ for treated rice straw with Trichoderma harzinaum $F-418$ (TH). The crude fiber content $\mathrm{CF} \%$ of rice straw before fungal treatment (control treatment) was $40.30 \%$. Results indicate that the crude fiber content decreased with the increased of fermentation time until 4 and 5 days. The crude fiber content values at the moisture level (M1) and the temperature levels $\mathrm{T}_{1}, \mathrm{~T}_{2}$ and $\mathrm{T}_{3}$ were 31.92, 28.55 and 30.85 respectively. At the moisture level $\left(\mathrm{M}_{2}\right)$, the crude fiber values were 33.10, 29.08 and 32.25 at temperature levels $T_{1}, T_{2}$ and $T_{3}$ respectively. While they were $30.97,28.35$ and 30.25 at the moisture level $\left(\mathrm{M}_{3}\right)$ and temperature levels $\mathrm{T}_{1}, \mathrm{~T}_{2}$ and $\mathrm{T}_{3}$ respectively. The statistical analysis of data showed that the crude fiber content was significantly affected by temperature, moisture and fermentation time. The crude fiber data showed 

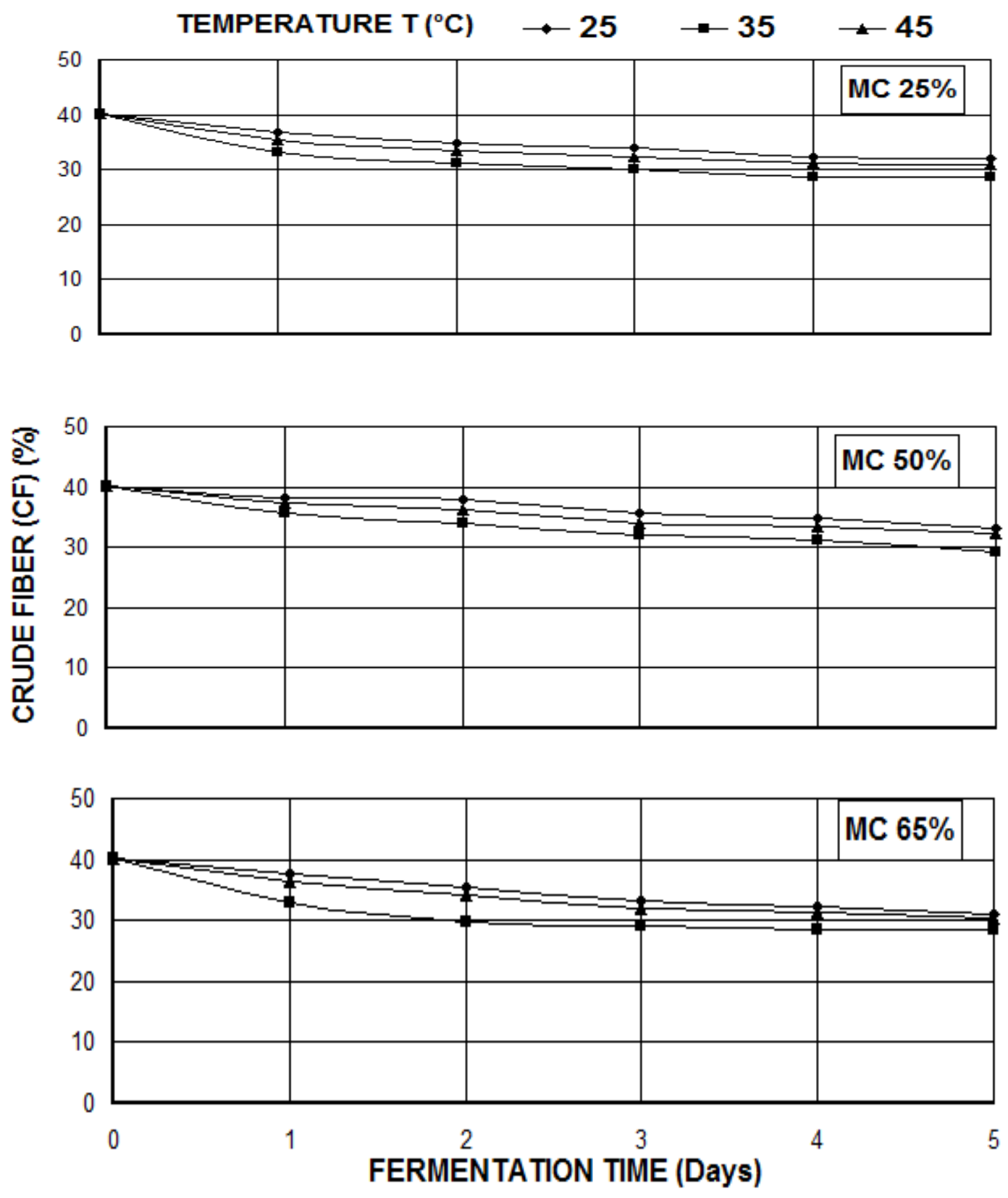

Figure (4): The effect of fermentation time (days) on crude Fiber content $\mathrm{CF}(\%)$ at different temperature and moisture levels.

that the treatment of $\mathrm{T}_{2} \mathrm{M}_{3}$ and fermentation time of 4 and 5 days gave the best value of crude fiber content where it was $28.35 \%$ by decreasing of $30 \%$ compared to the rice straw before fungal treatment (control 
treatment). Also, the treatments $\mathrm{T}_{2} \mathrm{M}_{1}$ and $\mathrm{T}_{2} \mathrm{M}_{2}$ showed decreasing of 29 $\%$ and $28 \%$ compared to the control treatment respectively. This may be due to the capture of excess nitrogen by aerobic microbes and conversion of the same into microbial protein during solid-state fermentation indicating their influence on hemicelluloses breakdown as the effect of the biological treatment These observations were agreement with Kholif (2005) and Mahrous (2005). Generally, the biological treatment with TH led to increase crude protein and reduce the crude fiber (similar results were reported by Langer et al. 1980). This may be due to the design of the bioreactor which allow to adequate aeration and mixing of the substrate. (Mixing and aeration have been explored by rotating paddles mounted on a shaft along the central axis.The growth of the inoculums in bioreactor is considered to be better and more uniform. Also water jacket around bioreactor removed the excess heat).

\section{CONCLUSION}

In this research, a development of bioreactor was made to enrich the protein of rice straw using solid-state fermentation. The fermentation time was 5 days and parameters related to microbial growth crude protein content \% (CP\%), and crude fiber content \% ( $\mathrm{CF} \%)$ were measured every $24 \mathrm{hr}$. The highest crude protein and the lowest crude fiber values were obtained at the temperature of $35{ }^{\circ} \mathrm{C}$ and the moisture content of $65 \%$ after 4 and 5 days. The best value of crude protein was $5.88 \%$ which increased $103 \%$ of the control treatment and the best value of crude fiber content was $28.35 \%$ wich decreased $30 \%$ of control treatment. It is evident that these values demonstrated good operation of fermentation in bioreactor.

\section{REFERENCES}

Abdel-Azim S. N., Ahmed M. A., F. Abo-Donia and H. Soliman (2011) Evaluation of fungal treatment of some agricultural residues, Egyptian Journal of Sheep \& Goat Sciences, Vol. 6 (2): 1 - 13.

AOAC. (1995) Association of Official Analytical Chemists, Official Methods of Analysis. 14 ${ }^{\text {th }}$ edition. Washington, DC, pp. 1018.

Abd El-Zaher, F. H., and M. Fadel (2010) Production of Bioethanol Via Enzymatic Saccharification of Rice Straw by Cellulase 
Produced by Trichoderma Reesei Under Solid State Fermentation, New York Science Journal: 72-78.

http://www.sciencepub.net/newyork, newyorksci@gmail.com

ATCC. (1992) Catalogue of Bacteria and Bacteriophages. American Type Culture Collection, $18^{\text {th }}$ Ed., p: 428. Maryland, USA.

Bart-Plange A., A. P. Mohammed-Kamil, A. Addo and E. Teye (2012) Some physical and mechanical properties of cashew nut and kernel grown in ghana, International Journal of Science and Nature (I.J.S.N)., 3(2): 406-415.

El-Ashry, M. A., H.M. El-Sayed, M. Fadel, H.M. Metwally and M. M. Khorshed (2002) Effect of chemical and biological treatments of some crop residues and their nutritive value: 2. Effect of biological treatments on chemical composition and in-vitro disappearance. Egyptian J. Nutrition and Feeds, 5: 43-54.

Hanafi, E. M., H.H. El Khadrawy, W. M. Ahmed and M. M. Zaabal (2012) Some Observations on Rice Straw with Emphasis on Updates of its Management. World Applied Sciences Journal, 16 (3): 354-361.

Hathout, M.K. and H., EL-Nouby (1977) Use of chopped corn stover as substitute for wheat straw in summer feeding of dairy cows. Agric.

Res. And Rev. Cairo, 55: 117.

Jonathan S. G., A. N Okorie, E. O Garuba, and O. J Babayemi (2012) Bioconversion of sorghum stalk and rice straw into value added ruminant feed using Pleurotus pulmonarius, Nature and Science, 10(4) 10-16. http://www.sciencepub.net/nature

Kholif, A. M., M. A. El- Ashry, H. A. El-Alamy, H.M. El-Sayed, M. fadel and S. M. Kholif (2005) Biological treatments of banana wastes for feeding lactating goats. Egyptian J. Nutrition and feeds 8(2): 149-162.

Langer, P.N.; J.P., Sehgal; and H.S., Garcha (1980). Chemical changes in wheat and paddy straw after fungal cultivation. Indian J. Anim. Sci., 50 (11): 942-946.

Lonsane, B. K., G. Saucedo-Castaneda, M. Rainbault, S. Roussos, G. 
Viniegra-Gonzalez, N. P. Ghildyal, M. Ramakrishna, M. M. Krishnaiah, (1992) Scale-up strategies for solid state fermentation systems, Process Biochem. 27: 259-273.

Mahrous, A. A. (2005) Effect of fungus treatments of cotton stalks on sheep performance. Egyptian J. Nutrition and feeds. 8 (2): 139148.

Negal, F. J. J. I., J. Tramper, M. S. N. Bakker, A. Rinzema, (2001) temperature control in a continuously mixed bioreactor for solid state fermentation. Biotechnol. Bioeng., 72 (9): 219-230.

Pandey A., C. R. Soccol, J. Rodriguez-Leon, P.Nigam (Eds.), (2001), Solid State Fermentation in Biotechnology, Asiatech Publishers Inc.,New Delhi, India.

Robinson, T. and P. Nigam (2003) Bioreactor design for protein enrichment of agricultural residues by solid state fermentation, Biochemical Engineering Journal, 13 (2-3): 197-203.

Roussos S., M. Raimbault, J. P Prebois, B. K Lonsane (1993) Zymotis, a large scale solid state fermenter. Appl Biochem Biotech. 42: 37-52.

Safa N. Abdel-Azim, Mona A. Ahmed, F. Abo-Donia and H. Soliman (2011). Evaluation of fungal treatment of some agricultural residues Egyptian Journal of Sheep \& Goat Sciences, Vol. 6 (2),1 - 13.

Sangsurasak P., T. Srinophakhun, and D. A. Mitchell (1997) Mathematical modeling development of packed bed bioreactors in solid-state fermentation. Kasetsart J. (Nat. Sci.), 31: 452-458.

Smail, T., O. Salhi and J. S. Knapp (1995) Solid-state fermentation of carob pods by Aspergillus niger for protein production: effect of particle size. World J. Microb. Biotech., 11:171

Snedecor, G.W. and W.G. Cochran (1971), Statistical Methods. 6 th Ed.,Iowa State Univ. Press, Ames, Iowa, USA.: 593.

Stuart D. M, D. A Mitchell, M. R Johns, J. D Litster (1999) Solid-state fermentation in rotating drum bioreactors: Operating variables affect performance through their effects on transport phenomena. Biotech Bioeng 63:383-391. 


\section{الملخص العربي \\ تطوير مفاعل حيوي لإثراء بروتين المخلفات الزراعية}

\section{محمد فايد عبد الفتاح خيري' ، أحمد على ابراهيم محمد` ومحمد محمود محمد نبيه خليلج}

تهذف هذه الدراسة إلى تعظيم استخدام المخلفات الزراعية وذلك بتصنيع وتطوير مخمر حيوي

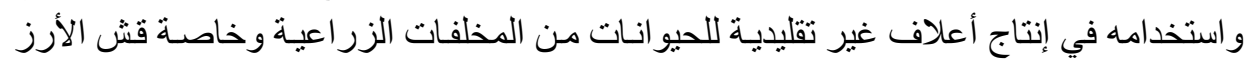
عن طريق المعاملة البيولوجية الهو ائية للمخلفات الزر اعية باستخدام بعض الكائنات الحية الدقيقة

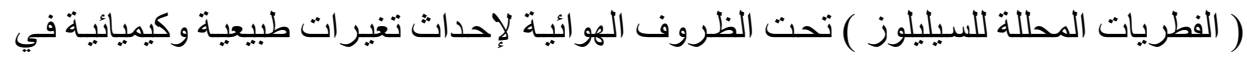
مكونات المخلفات الزر اعية بهدف تحسين استساغتها وقيمتها الغذائية. في هذه الدراسة تم دراسية تأثير ثناث مسنتويات لدرجة الحرارة

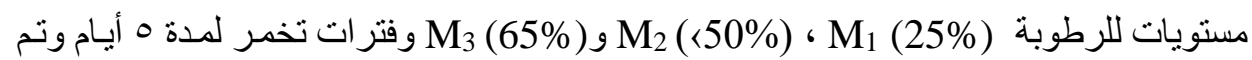

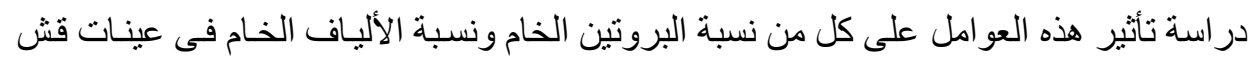

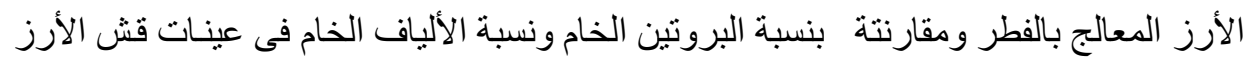

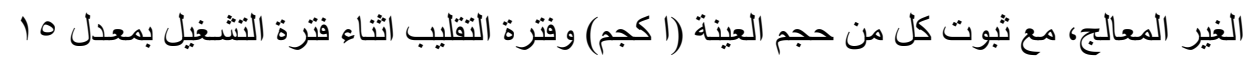

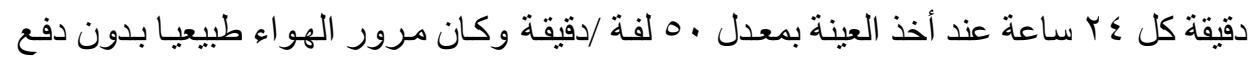

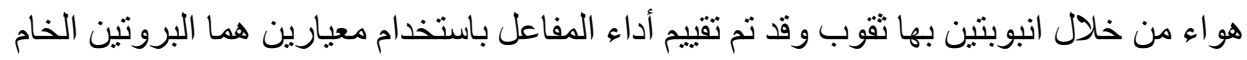

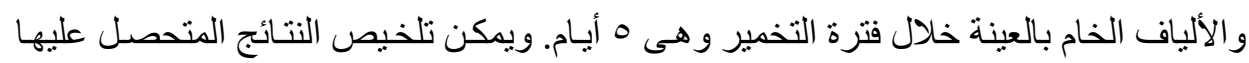

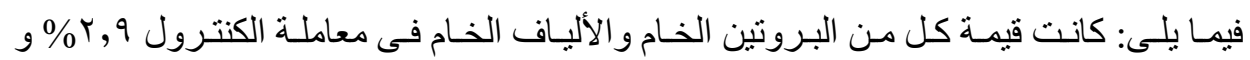

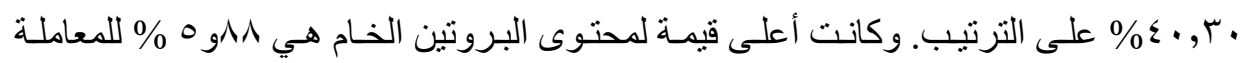
T2 T2

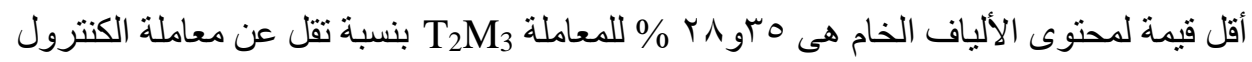

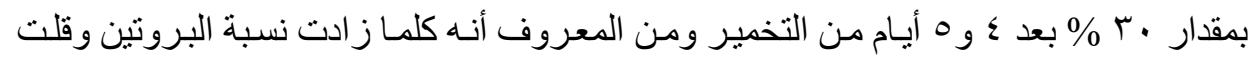

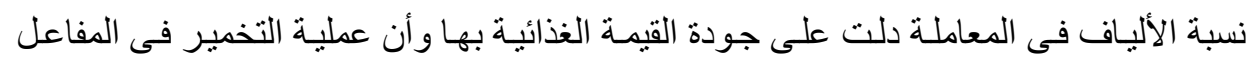

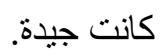

' أستاذ القوى والألات الزراعيةـ كلية الهندسة الزراعية ـ جامعة الأزهر مصر.

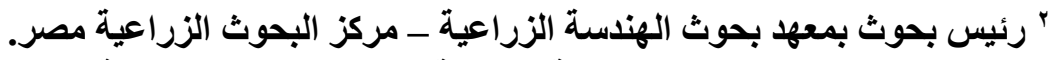

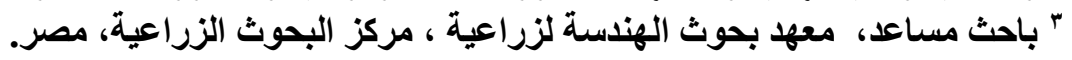

